\title{
The Nutraceutical Value of Carnitine and Its Use in Dietary Supplements
}

Alessandra Durazzo ${ }^{1, *} * \mathbb{D}$, Massimo Lucarini ${ }^{1}$, Amirhossein Nazhand ${ }^{2}$, Selma B. Souto ${ }^{3}$, Amélia M. Silva ${ }^{4,5}$, Patrícia Severino ${ }^{6,7,8}$, Eliana B. Souto ${ }^{9,10}$, and Antonello Santini ${ }^{11, *(1)}$

1 CREA-Research Centre for Food and Nutrition, Via Ardeatina 546, 00178 Rome, Italy; massimo.lucarini@crea.gov.it

2 Department of Biotechnology, Sari Agriculture Science and Natural Resource University, 9th km of Farah Abad Road, Sari 48181 68984, Mazandaran, Iran; nazhand.ah@gmail.com

3 Department of Endocrinology of Hospital São João, Alameda Prof. Hernâni Monteiro, 4200-319 Porto, Portugal; sbsouto.md@gmail.com

4 Department of Biology and Environment, University of Trás-os-Montes e Alto Douro (UTAD), Quinta de Prados, P-5001-801 Vila Real, Portugal; amsilva@utad.pt

5 Centre for Research and Technology of Agro-Environmental and Biological Sciences (CITAB), University of Trás-os-Montes e Alto Douro (UTAD), P-5001-801 Vila Real, Portugal

6 Industrial Biotechnology Program, University of Tiradentes (UNIT), Av. Murilo Dantas 300, Aracaju 49032-490, Brazil; pattypharma@gmail.com

7 Tiradentes Institute, 150 Mt Vernon St, Dorchester, MA 02125, USA

8 Laboratory of Nanotechnology and Nanomedicine (LNMED), Institute of Technology and Research (ITP), Av. Murilo Dantas, 300, Aracaju 49010-390, Brazil

9 Department of Pharmaceutical Technology, Faculty of Pharmacy, University of Coimbra, Pólo das Ciências da Saúde, Azinhaga de Santa Comba, 3000-548 Coimbra, Portugal; souto.eliana@gmail.com

10 CEB-Centre of Biological Engineering, University of Minho, Campus de Gualtar, 4710-057 Braga, Portugal

11 Department of Pharmacy, University of Napoli Federico II, Via. D. Montesano 49, 80131 Napoli, Italy

* Correspondence: alessandra.durazzo@crea.gov.it (A.D.); asantini@unina.it (A.S.); Tel.: +39-(0)6-514-94-430 (A.D.); +39-(0)81-253-9317 (A.S.)

Academic Editors: Cesare Indiveri and Lara Console Received: 7 April 2020; Accepted: 28 April 2020; Published: 1 May 2020

\begin{abstract}
Carnitine can be considered a conditionally essential nutrient for its importance in human physiology. This paper provides an updated picture of the main features of carnitine outlining its interest and possible use. Particular attention has been addressed to its beneficial properties, exploiting carnitine's properties and possible use by considering the main in vitro, in animal, and human studies. Moreover, the main aspects of carnitine-based dietary supplements have been indicated and defined with reference to their possible beneficial health properties.
\end{abstract}

Keywords: carnitine; food supplements; nutraceuticals; in vitro studies; in animal studies; in humans studies

\section{Carnitine: An Overview of Its Main Features}

Carnitine (n3-hydroxy-4-N,N,N-trimethylaminobutyrate; 3-hydroxy-4-(trimethylazaniumyl) butanoate (IUPAC name); $\beta$-hydroxy- $\gamma-N$-trimethylaminobutyric acid) is an amino acid derivative that exists as one of the $\mathrm{D} / \mathrm{L}$ stereoisomers, $\mathrm{L}$-carnitine being the biologically active isomer form of carnitine, naturally occurring in animals, while the D-carnitine is also active, but inhibits the effect of L-carnitine and is toxic. It is a naturally occurring endogenous metabolite which can be found in most mammals, it is a water-soluble molecule, and it has been reported to have many biological functions. Carnitine can be considered as a conditionally essential nutrient for its importance in human physiology [1]. The molecular structure of carnitine $\left(\mathrm{C}_{7} \mathrm{H}_{15} \mathrm{NO}_{3}, \mathrm{MW}=161.2 \mathrm{~g} / \mathrm{mol}\right.$, solubility 
$>2500 \mathrm{~g} / \mathrm{L}$ at a temperature of $20^{\circ} \mathrm{C}$; PubChem CID: 288) is shown in Figure 1. At a pH value of 3.8, it is a zwitterion, due to positively charged quaternary ammonium groups and carboxylate, and it dissolves easily in water at a temperature of $20^{\circ} \mathrm{C}$.

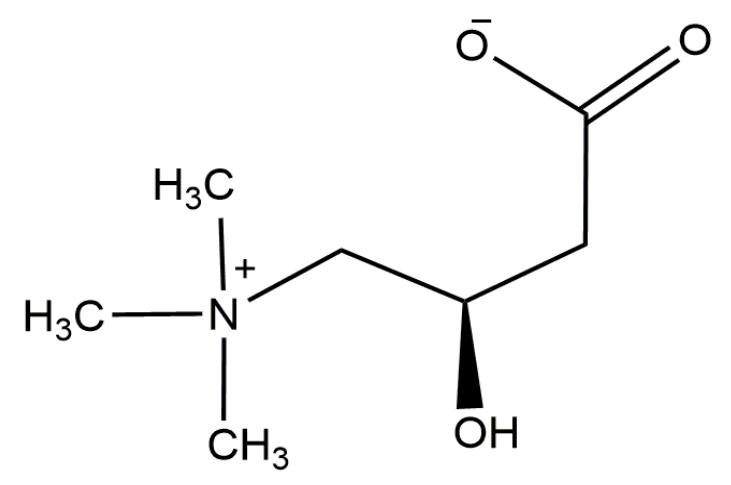

Figure 1. Chemical structure of L-carnitine.

Carnitine is a vitamin-like substance (or "quasi-vitamins" [2]) and acts as a coenzyme, and its function is relevant, being necessary to deliver long-chain fatty acids (LCFAs) from the cytosol into the mitochondrial matrix. This can occur via carnitine palmitoyltransferase 1 (CPT1) in the outer mitochondrial membrane, thereby playing a role in energy supply to the body through the $\beta$-oxidation of LCFAs [3,4]. While defects in carnitine biosynthesis do not result in carnitine deficiency, severe plasma and intracellular carnitine depletion occurs due to defects in carnitine transport [5]. Carnitine homeostasis is maintained by diet and renal absorption (as only a small amount is obtained by endogenous biosynthesis). Renal absorption of carnitine occurs via cation transporter-2 (OCTN2; a high-affinity plasma-membrane sodium-dependent carnitine transporter), and by cation transporter-1 (OCTN1), with lower carnitine affinity than OCTN2. OCTN2 expression is not limited to kidney; it is found on many other cells (e.g., polarized intestinal cells, liver, heart, skeletal muscle, placenta, brains, and others) to guarantee carnitine absorption and distribution [5]. Defects in OCTN2, due to autosomal recessive mutations in the SLC22A5 gene, result in carnitine deficiency, as a consequence of reduced carnitine transport and intracellular accumulation, increased urine excretion of carnitine and decreased serum levels of carnitine. Due to reduced intracellular levels of carnitine, defective fatty acid oxidation occurs, leading to glucose consumption instead of lipid consumption, even during fast, resulting in hypoglycemia; meanwhile, non-metabolized lipids (together with lipids released from adipose tissue) accumulate in tissues such as heart, skeletal muscle, and liver, resulting in myopathy and hepatic steatosis [6]. Therefore, researchers have proposed the measurement and detection of autosomal recessive carnitine deficiency in newborn screening programs [7-10]. Beyond its relevant role in fatty acid transport and oxidation, carnitine also acts as a free radical scavenger in different tissues, and also maintains cellular free coenzyme A levels [11,12]. The endogenous essential amino acids L-methionine and L-lysine are responsible for the formation of carnitine (known as a branched non-essential amino acid) in various tissues, such as brain, kidney, and predominantly liver. Meat, poultry, fish, and dairy foods, and, recently, dietary supplements supply $75 \%$ of carnitine [13]. The main animal source of carnitine is red meat (which contains up to $80 \mu \mathrm{g} / 100 \mathrm{~g}$ ); it is present in moderate amounts in dairy products, and at a low-to-zero level in vegetables [14]. Endogenous production accounts for about $25 \%$. Carnitine is easily absorbed from foodstuffs (up to $60-70 \%$ ), but thermal treatments, e.g., cooking on open flames at high temperatures, can lower carnitine levels and consequently its bioavailability. Carnitine exists in two enantiomers, namely D-carnitine and L-carnitine, which are related to the presence of one chiral carbon: L-carnitine is the physiologically active form, as well as propionyl-L-carnitine and acetyl-L-carnitine, two derivatives which are also bioactive compounds. The structures of these derivatives are shown in Figure 2. 
<smiles>CC(=O)O[C@H](CC(=O)[O-])C[N+](C)(C)C</smiles>

acetyl-L-carnitine<smiles>CCC(=O)O[C@H](CC(=O)[O-])C[N+](C)(C)C</smiles>

propionyl-L-carnitine

Figure 2. Chemical structure of acetyl-L-carnitine and propionyl-L-carnitine.

The biological functions of carnitine are summarized in Figure 3. Many health-beneficial actions of carnitine have been identified and reported, including suppression of apoptosis, correction of cytotoxicity by excessive acyl groups, and stabilization of the erythrocyte membrane [15] and anti-inflammatory and antioxidant properties [16]. It has also been reported that carnitine can improve insulin resistance [17], and it is useful in cardiovascular diseases [18,19] and cancer [20].

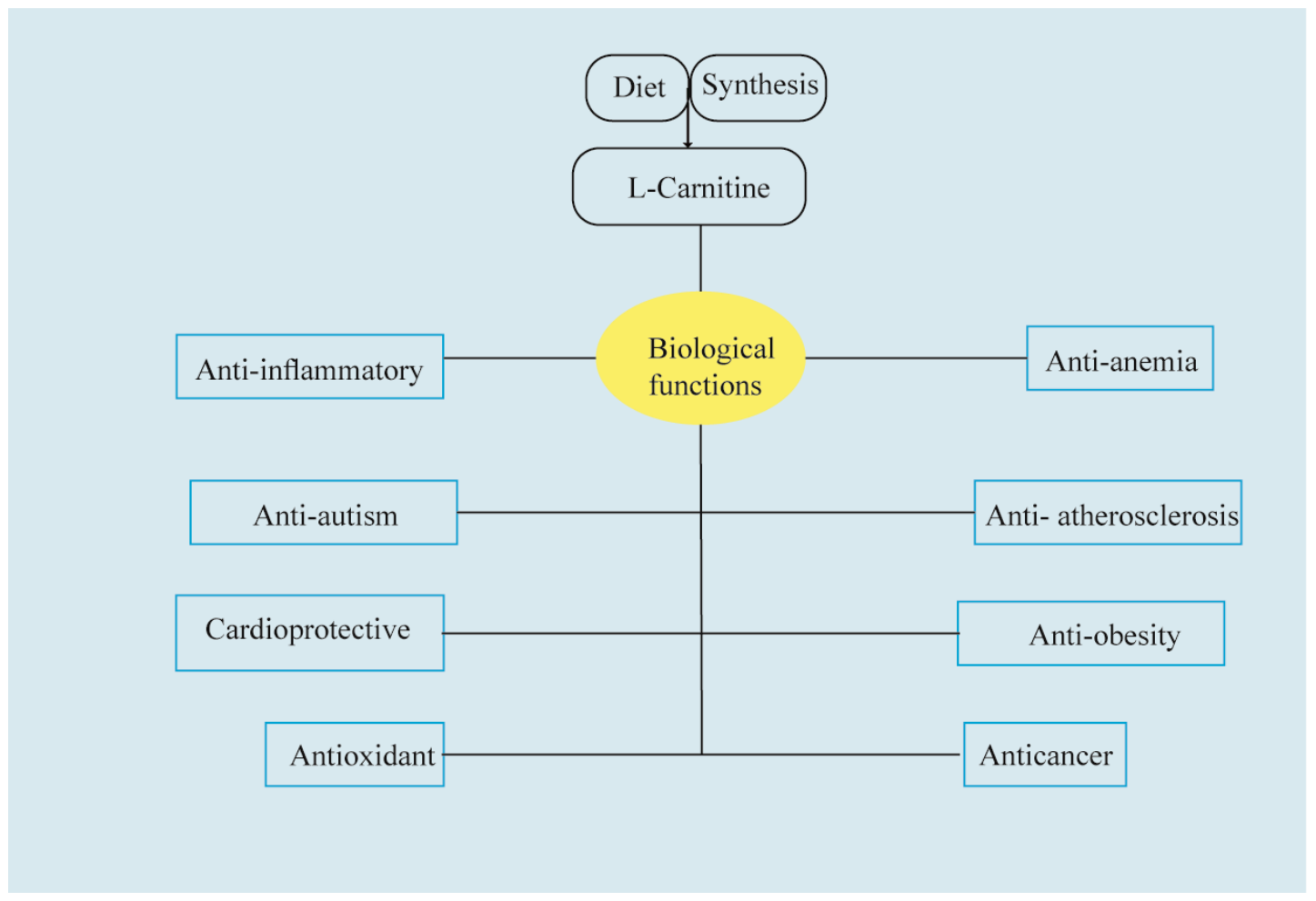

Figure 3. Overview of carnitine biological activities.

Moreover, it has been found by Hathcock et al. that carnitine can be considered a safe nutrient [21], with adverse outcomes typically limited to mild gastrointestinal discomfort when individuals ingest high dosages ( $>5 \mathrm{~g} /$ day). L-carnitine at a concentration of $2000 \mathrm{mg} /$ day is considered to be unlikely 
to provoke unwanted side effects and is safe for human beings [21]. The administration of carnitine supplements has been documented for its safety and efficiency and reported in many studies [14,21].

\section{An Updated Shot of Beneficial Properties: In Vitro and In Vivo Studies}

Many in vitro studies [22-29], and in vivo studies of animals [30-47] and humans [48-59] have reported different beneficial functions for carnitine. In the following, the main activities observed are reported.

\subsection{In Vitro Activity}

Relevant in vitro studies on L-carnitine are reported in Table 1.

Table 1. An up-to-date picture of in vitro studies of L-carnitine.

\begin{tabular}{|c|c|c|c|}
\hline Condition & Activity & Effect & References \\
\hline In vitro & Anticancer effects & $\begin{array}{l}\text { Reduced the levels of methylmalonicacidemia and Propionic } \\
\text { acidemia in peripheral leukocytes. }\end{array}$ & [22] \\
\hline In vitro & Antioxidant effects & L-carnitine could elevate in vitro human sperm motility. & [23] \\
\hline In vitro & Antioxidant effects & $\begin{array}{c}\text { Inhibited acrylamide-induced genotoxicity in human lymphocytes } \\
\text { through the improvement of oxidative stress. }\end{array}$ & [24] \\
\hline In vitro & Antioxidant effects & Inhibited ROS production and reduced antioxidant activity. & [25] \\
\hline In vitro & Anti-aging effect & $\begin{array}{l}\text { Decreased epigenetic modification of hTERT gene promoter and the } \\
\text { numbers of senescent cells, and increased activity of telomerase. }\end{array}$ & [26] \\
\hline In vitro & Hepatoprotective effect & $\begin{array}{l}\text { Inhibited the inflammatory mediator iNOS through the suppression } \\
\text { of NF-kB activity in IL-1 } \beta \text {-stimulated hepatocytes. }\end{array}$ & [27] \\
\hline In vitro & Anti-angiogenic effect & $\begin{array}{c}\text { Suppressed the activation of ICAM-1 and NF-kB and } \\
\text { down-regulated the activation of FAK, CXCR4, CXCL12, VEGFR2 } \\
\text { and VEGF pathways. }\end{array}$ & [28] \\
\hline In vitro & Neuroprotective effect & Inhibited methamphetamine-induced activation of MMP-9 & [29] \\
\hline
\end{tabular}

Carnitine showed in vitro anticancer activity by preventing colon cancer cell (Caco-2 cells) proliferation via a reduction in prostaglandin E2 synthesis and induction of colon cancer cell apoptosis [60]. In several prostate cancer cell lines, acetyl-L-carnitine acted as an anti-prostate cancer agent by inhibiting the production of chemokines CXCL12 and CCL2 as well as CXCR4 (chemokine ligand-receptor) and pro-inflammatory cytokines (IFN- $\gamma$ and TNF- $\alpha$ ) [61]. Huang et al. evaluated the in vitro anticancer role of carnitine in samples of HepG2 tumor-bearing mice, primary cultured thymocytes, human SMMC-7721, and hepatoma HepG2 cell lines. The main findings, following L-carnitine treatment, were prevention of cancer cell growth; inhibition of Histone Deacetylases HDAC I/II activities caused by L-carnitine binding to HDAC active sites; elevation of histone acetylation and acetylated lysine accumulation; and induction of $\mathrm{p} 21^{\mathrm{cip} 1}$ gene, mRNA and protein expression in cancer cells [62].

Pre-treatment with acetyl-L-carnitine and L-carnitine exhibited neuroprotective activity for prevention of hypoxia-ischemia injury, via an increase in the activity levels of ATPase and superoxide dismutase (SOD) as well as a decrease in the level of malondialdehyde (MDA), oxygen-glucose deprivation (OGD)-induced cell death, injury and apoptosis [63]. The in vitro L-carnitine has been reported to reduce phenylalanine-induced DNA damage [64]. The administration of acetyl-L-carnitine (500 $\mu \mathrm{M})$ exhibited a neuroprotective role by restoring synaptic plasticity and transmission [65]. In a study by Bavari et al. [66], the neuroprotective effect of L-carnitine $(5 \mathrm{mM})$ controlled, within $18 \mathrm{~h}$, caffeine cytotoxicity through the regulation of apoptosis-related caspase- 3 activity, reducing the DNA fragmentation, inhibition of reactive oxygen species (ROS) generation, elevation of endogenous anti-oxidant defense systems, and the prevention of lipid oxidation. In vitro accumulated L-carnitine has been used to control DNA damage and oxidative damage in patients with mitochondrial fatty acid oxidation disorders [67].

L-carnitine has been also shown to manage fructose-induced hepatic steatosis in HepG2 cells, due to activation of antioxidant system, maintenance of mitochondrial homeostasis, and regulation of Nrf2 (nuclear factor erythroid 2-related factor 2) and SOD activity [68]. L-carnitine can increase antioxidant and mitochondrial functions in human osteoblast-like cells, via up-regulation of osteopontin, bone 
sialoprotein, transcription factor Sp7(Osterix), and RUNX2 genes; phosphorylation of AKT and ERK1/2; and enhanced phosphorylation of $\mathrm{Ca}^{2+} /$ calmodulin-dependent protein kinase II [69]. In vitro post-oxidative stress glaucoma was controlled by carnitine through reducing pathologic optic-disk excavation, typical cell stress markers such as caspase 3 and ubiquitin, inducible nitric oxide synthase, and glial fibrillary acidic protein expression [70]. In a recent study, the lifespan of human mesenchymal stem cells obtained from aged participants was prolonged, by lengthening telomere and increasing the expression of the $h T E R T$ gene, following the use of L-carnitine $(0.2 \mathrm{mM})$ for two days [71]. In an in vitro study, performed in blood leukocytes, by Rodrigues et al. [72], administration of L-carnitine (30 and $150 \mu \mathrm{M})$ prevented DNA damage induced by L-2-hydroxyglutaric and D-2-hydroxyglutaric in L-2-hydroxyglutaric-aciduria-affected patients. The effects of L-carnitine on different parameters of oxidative stress induced by menadione have been evaluated in myoblastic $\mathrm{C} 2 \mathrm{C} 12$ cells: the results indicated a reduction in autophagy and ROS production [73]. In another recent study, human sperm morphology and sperm count were improved by $40 \mu \mathrm{g}$ L-carnitine + coenzyme Q10 (CoQ10) treatment, while DNA fragmentation was reduced [74].

\subsection{In-Animal Studies}

Table 2 presents an updated picture of studies based on L-carnitine which have been conducted in animals.

Table 2. An updated picture of studies based on L-carnitine conducted inanimal models.

\begin{tabular}{|c|c|c|c|}
\hline Condition & Activity & Effect & References \\
\hline In-animal model & Antioxidant effects & $\begin{array}{l}\text { Symptom improvement observed by inducing potential function } \\
\text { of the CNS and short-term plasticity. }\end{array}$ & {$[30]$} \\
\hline In-animal model & Antioxidant effects & $\begin{array}{l}\text { Impeded age-related mitochondrial dysfunction by reducing } \\
\text { oxidative stress, age-related alterations of mitochondrial dynamics } \\
\text { and biogenesis, and activation of PGC- } 1 \alpha / \beta \text { coactivators. }\end{array}$ & [31] \\
\hline In-animal model & Anti-diabetic effects & $\begin{array}{c}\text { An improvement of glucose metabolism in mice with insulin } \\
\text { resistant }\end{array}$ & [32] \\
\hline In-animal model & Anti-diabetic effects & Reduction in the serum levels of adiponectin. & [33] \\
\hline In-animal model & $\begin{array}{l}\text { Anti-inflammatory and } \\
\text { anti-oxidant effects }\end{array}$ & $\begin{array}{l}\text { Managed histological and inflammation damage, apoptosis, } \\
\text { mitochondrial dysfunction and arsenic-induced hepatotoxicity. }\end{array}$ & [34] \\
\hline In-animal model & Antioxidant effect & $\begin{array}{c}\text { Upregulation of } n r f 2 \text { expression and elevation of GSH and TAC } \\
\text { levels. }\end{array}$ & [35] \\
\hline In-animal model & Cardioprotective effect & $\begin{array}{l}\text { Controlled the cardiac toxicity induced by } 75-\text { and } 150-\mathrm{mg} / \mathrm{Kg} \text { BW } \\
\text { aspartme. }\end{array}$ & [36] \\
\hline In-animal model & Anti-obesity effect & Reduction in elevated plasma lipids in obese Zucker rats. & [37] \\
\hline In-animal model & $\begin{array}{l}\text { Immunostimulatory } \\
\text { and radioprotective } \\
\text { role }\end{array}$ & $\begin{array}{l}\text { Reduced sperm abnormalities, modified severe tubular } \\
\text { degeneration and increased serum testosterone levels. }\end{array}$ & [38] \\
\hline In-animal model & $\begin{array}{l}\text { Enhanced exercise } \\
\text { endurance }\end{array}$ & $\begin{array}{l}\text { Reduced body fat, increased maximum running time, and } \\
\text { elevated mitochondrial biogenesis, oxidative metabolism and } \\
\text { fatty acid adsorption. }\end{array}$ & [39] \\
\hline In-animal model & Cardioprotective effect & Inhibited 6-Gy $\gamma$-radiation-induced toxicity. & [40] \\
\hline In-animal model & Antioxidant effect & Prevented $\mathrm{NaAsO} 2$-induced oxidative damage in rat. & [41] \\
\hline In-animal model & $\begin{array}{l}\text { Treatment of muscle } \\
\text { atrophy }\end{array}$ & $\begin{array}{l}\text { Prevented muscle atrophy by inhibiting the ubiquitin proteasome } \\
\text { pathway. }\end{array}$ & {$[42]$} \\
\hline In-animal model & $\begin{array}{l}\text { Anti-atherosclerosis } \\
\text { effect }\end{array}$ & Prevented the production of trimethylamine N-oxide. & [43] \\
\hline In-animal model & Antioxidant effect & $\begin{array}{l}\text { Decreased the oxidative stress at least in the heart of } \\
\text { oophorectomized rats. }\end{array}$ & [44] \\
\hline In-animal model & Antioxidant effect & $\begin{array}{c}\text { Decreased acrylamide-toxicity in spleen and thymus tissues in } \\
\text { mice. }\end{array}$ & [45] \\
\hline In-animal model & Antioxidant effect & $\begin{array}{c}\text { L-carnitine }(200 \mathrm{mg} / \mathrm{kg} \mathrm{BW}) \text { for } 11 \text { weeks prevented dimethoate } \\
\text { toxicity in rats. }\end{array}$ & [46] \\
\hline In-animal model & Antioxidant effect & $\begin{array}{l}\text { Reduction in PCC (protein oxidation marker), TBARS (lipid } \\
\text { peroxidation marker), caspase-3, DNA fragmentation, } \\
\text { cyclobutane pyrimidine dimers, 8-oxo-2'-deoxyguanosine } \\
\text { (8-oxo-dG) as well as proinflammatory cytokines IL-1 } \beta, \text { IL-6, and } \\
\text { TNF- } \alpha \text { downregulation, upregulation of PCNA (DNA repair } \\
\text { proliferating cell nuclear antigen) protein, removed c-Fos and } \\
\text { oxidative stress-sensitive signaling protein p38. }\end{array}$ & [47] \\
\hline
\end{tabular}


Taking the anti-histamine drugs cetirizine hydrochloride and chlorpheniramine maleate combined with L-carnitine showed a hepatoprotective effect in animal models, via a reduction in oxidative stress and an improvement in liver function due to the elevation of serum albumin levels and a reduction in serum alkaline phosphatase (ALP), aspartate transferase (AST), and alanine transferase (ALT) levels; this treatment also enhanced hepatic glutathione (GSH) levels and reduced hepatic MDA compared with a control [75]. Ahmed et al. used $50 \mathrm{mg} / \mathrm{kg} /$ day of atorvastatin in rats for induction of hepatoxicity, and then utilized $300 \mathrm{mg} / \mathrm{kg} /$ day of oral L-carnitine and $500 \mathrm{IU} / \mathrm{kg} /$ day of oral vitamin D3. Their results showed a decrease in serum levels of creatine kinase, aspartate aminotransferase, and alanine aminotransferase. Furthermore, histological examinations revealed protection of muscle and liver tissues against the toxic effects of atorvastatin [76]. The use of nicotinamide riboside plus L-carnitine in high-fat-diet-treated mice with non-alcoholic fatty liver disease induced anti-obesogenic hepatoprotective activity due to regulation of INSR, PPARGC1B, SREBF, SCAP, and ACOX, as well as reduction of hepatic steatosis, fat mass, and obesity [77]. Administration of $200 \mathrm{mg} / \mathrm{kg} / \mathrm{day}$ of coenzyme $\mathrm{Q} 10$ plus $50 \mathrm{mg} / \mathrm{kg} /$ day of L-carnitine in CCl4 hepatoxicity-induced rats exhibited the prophylactic effect observed [78]. In a recent study, L-carnitine showed a free radical scavenger effect in ethanol-intoxicated rats through the inhibition of hepatocyte function modification [79]. Induction of renal and pancreatic injuries by cyclosporine $(15 \mathrm{mg} / \mathrm{kg} /$ day) in rats was treated by L-carnitine ( 50 or $200 \mathrm{mg} / \mathrm{kg} /$ day) for a month, the result of which was inhibition of LC3-II and caspase-3 expression, suppression of 8-OHdG and TGF- $\beta 1$ expression, improved inflammation and renal function, decreased $\mathrm{HbA} 1 \mathrm{c}$ and plasma glucose levels, and elevated plasma insulin level [80]. In another study, the use of L-carnitine prevented non-alcoholic steatohepatitis in mice by blocking inflammatory cytokines, preventing hepatic oxidative stress markers and elevating hepatic gene expression [81].

The administration of acetyl-L-carnitine prevented atherosclerosis onset in Wistar rats by blocking the expression of oxidative-stress-related genes, controlling inflammation parameters, and regulating blood lipids, as well as displaying myocardial protection and acting against atherosclerotic cardiovascular disease, by reducing mRNA levels, iNOS, IL-1b, TNF-a and CPR protein in the hearts and aortas of rats with induced atherosclerosis [82]. Blanca et al. found that sunitinib produced cardiac toxicity via the involvement of fibrotic and inflammation processes mediated by transcription factor NF-kB, and they also reported that L-carnitine showed a protective effect against secondary fibrotic process, cardiac inflammation, and arterial hypertension induced with sunitinib in Wistar rats [83]. Co-administration of $300 \mathrm{mg} / \mathrm{kg}$ of L-carnitine plus $10 \mathrm{mg} / \mathrm{kg}$ of olmesartan could control doxorubicin-induced $(20 \mathrm{mg} / \mathrm{kg}$ ) cardiotoxicity in rats, through elevation of cardiac levels of glutathione and superoxide dismutase and reduction of cardiac levels of malondialdehyde, transforming growth factor Beta, NF-kB, myeloperoxidase, Interleukin IL-1 $\beta$, intercellular adhesion molecules-1, tumor necrosis factor-alpha and caspase-3 [84]. The supplementation of propionyl-L-carnitine in a hamster cheek pouch with ischemia-reperfusion injury prevented microvascular modifications through a reduction in E-selectin expression, resulting in permeability enhancement and poor leukocyte adhesion [85]. In one study, L-carnitine showed an antihypertensive function in rats with heart failure with preserved ejection fractions through an increasing the prostacyclin synthesis and the expression of fatty acid desaturase, respectively [86]. The use of L-carnitine ( $400 \mathrm{mg} / \mathrm{kg} / \mathrm{day})$ had a health-promoting effect on hypertension-associated cardiac fibrosis in rats through the down-regulation of CTGF, TGF- $\beta 1$ and NOX2/4, and a reduction in cardiac fibrosis [87].

The use of L-carnitine plus selenium for a month to treat cadmium-induced damage in male mice during could reduce DNA damage and histopathological abnormalities and increase the activity of antioxidant enzymes [88]. The treatment of rats with L-carnitine $(50 \mathrm{mg} / \mathrm{kg} / \mathrm{day})$ for $7 \mathrm{months}$ exhibited antioxidant properties by regulating Bax and Bcl-2, dropping caspase-3 activity, elevating total antioxidant activity, and scavenging oxygen free radicals [89]. Others reported that the administration of L-carnitine $(500 \mathrm{mg} / \mathrm{kg}$ ) showed antioxidant and protective effects on testicular ischemia-reperfusion damage in rats [90]. In a study by Boyacioglu et al., the use of L-carnitine in rats controlled contrast-induced nephropathy through a preventative function [91]. 
In a recent study, adult male rats received busulfan plus L-carnitine/arginine, and, as a result, showed reduced busulfan cytotoxicity, conserved cell energy, reduced oxidative stress, and better semen parameters [92]. Masoumi-Ardakani et al. [93] administered $300 \mathrm{mg} / \mathrm{kg} / \mathrm{day}$ of L-carnitine to 48 male rats with Streptozotocin-induced diabetes for 35 days and observed an increase in pancreatic and serum levels of glutathione peroxidase, superoxide dismutase, and total antioxidant status. Others reported that bone microstructural features were improved and bone resorption was slowed following the administration of L-carnitine in aging ovariectomized rats, due to the reduction in bone turnover [94]. Evaluating the effect of hyperbaric oxygen on lipid metabolism dysfunction in high fat diet-fed mice showed an increase in the expression of $\operatorname{PPAR} \alpha$, skeletal muscle and circulation levels of L-carnitine [95]. In one study, $300 \mathrm{mg} / \mathrm{kg} /$ day of acetyl-L-carnitine for 28 days in rats attenuated OP-induced haemotoxicity [96].

\subsection{In Human Studies}

An up-to-date picture of studies conducted in humans is presented in Table 3.

Table 3. An up-to-date picture of in vivo studies of L-carnitine.

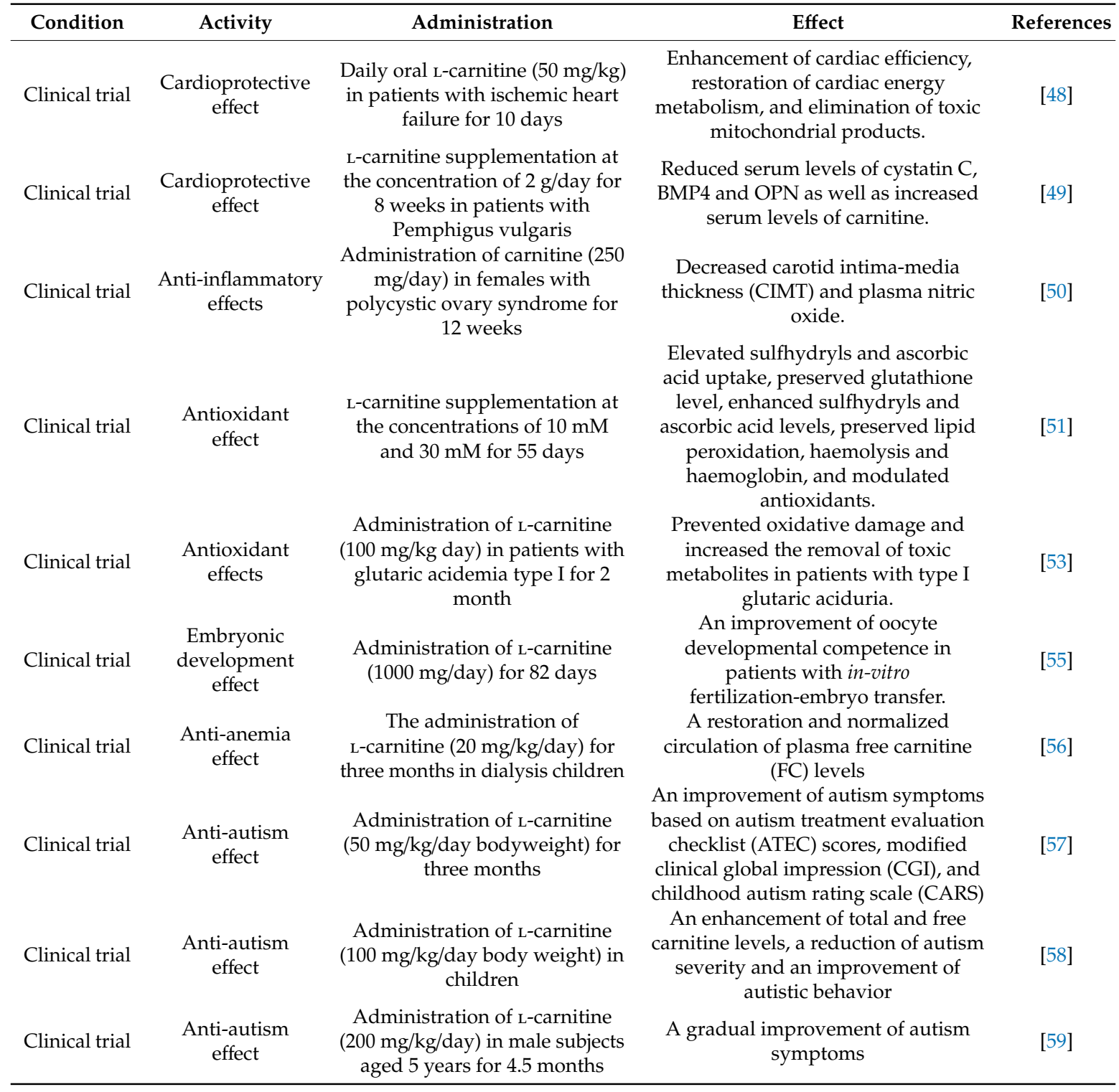


The findings of a recent systematic review and meta-analysis of randomized clinical trials regarding L-carnitine supplementation showed an amelioration of muscle soreness and an improvement in muscle damage biomarkers, due to a decrease in lactate dehydrogenase, myoglobin and creatine kinase [97]. In a study by Chae et al. [98], daily administration of two or three $500-\mathrm{mg} / \mathrm{L}$-carnitine tablets reduced imatinib-induced muscle cramps in gastrointestinal stromal tumor (GIST) patients. A $750 \mathrm{mg} / \mathrm{day}$ dose of L-carnitine for 8 weeks in female patients with knee osteoarthritis reduced the pain intensity and serum inflammatory mediators such as matrix metalloproteinases- 1 and Interleukine- $1 \mathrm{~b}$ [99]. In a recent study, supplementation of L-carnitine $(750 \mathrm{mg} /$ day) for 8 weeks in patients with osteoarthritis caused knee pain improvement and reduced serum inflammatory markers (namely MMP-1, and IL-1 $\beta)$ [99].

Kazemian et al. [100] reported a neuroprotective function in 100 patients with ischemic cerebrovascular injury, following the use of fat emulsion and L-carnitine, which decreased S100B biomarker levels. Reportedly, patients with painful peripheral neuropathy have been treated by the administration of acetyl-L-carnitine [101].

Abolfathi et al. [102] conducted a clinical trial to evaluate the effect of carnitine in patients with nonalcoholic fatty liver disorder and found a decrease in homeostasis model assessment of insulin resistance, triglycerides, alanine aminotransferase, and aspartate aminotransferase. In a systematic review and meta-analysis by Thiagarajan et al. [103], the effect of dietary L-carnitine supplementation was reviewed quantitatively and qualitatively in randomized trials (sample size of 338 individuals) from Iran, South Korea, and Italy. Decreases in Homeostatic Model Assessment for Insulin Resistance (HOMA-IR), liver fat, and serum alanine aminotransferase have also been reported [103]. Oral L-carnitine showed a hepatoprotective effect due to a decrease in the levels of gamma-glutamyltransferase, aspartate aminotransferase, and alanine aminotransferase [104].

L-carnitine supplementation in elderly hemodialyzed patients with end-stage kidney disorder increased amino acid metabolism, fatty acid metabolism, blood acy L-carnitine levels, and energy production in skeletal and heart muscles [105]. Others found $50 \mathrm{mg} / \mathrm{kg}$ L-carnitine for 6 to $10 \mathrm{months}$ in children treated with hemodialysis pediatric at 18 years of age by reduction of parathyroid hormone level, which led to maintained bone density and decreased bone resorption [106]. In one study, in pediatric peritoneal dialysis, patients observed reduction of apolipoprotein B levels with $50 \mathrm{mg} / \mathrm{kg}$ per day of L-carnitine supplementation for a month [107]. Sheikhi et al. [108] found no change in Apo AI and SB100 levels following use of L-carnitine. One study outlined the great risk of carnitine deficiency: carnitine insufficiency and the prevalence of carnitine deficiency were estimated at $73.5 \%, 82.3 \%$ and $8.8 \%$ among dialyzed patients, respectively [109]. L-carnitine displayed a cardioprotective function in women after six months, increasing D-loop methylation in platelets and reducing the low-density lipoprotein cholesterol level and trimethylamine- $N$-oxide level [110]. Bavbek et al. [111] reported that the use of carnitine $(20 \mathrm{mg} / \mathrm{kg})$ three times a week for six months in chronic hemodialyzed patients could increase total and free carnitine levels by improving forced expiratory volume in one second and forced vital capacity, leading to management of respiratory dysfunction.

Patients with phenylketonuria receiving L-carnitine $(98 \mathrm{mg} /$ day) combined with selenium (31.5 micrograms/day) for six months showed the restoration of GSH-Px activity, and the improvement of protein and lipid oxidative damage [112]. Chromium picolinate (at a dose of $200 \mu \mathrm{g} /$ day) combined with carnitine $(1000 \mu \mathrm{g} /$ day $)$ in women with polycystic ovary syndrome for 12 weeks showed a significant improvement of stress, depression, and anxiety [113].

Administration of $\mathrm{L}$-carnitine in patients with maple syrup urine disease prevented DNA damage induced by alloisoleucine, branched-chain $\alpha$-keto-acids and branched-chain amino acids [114]. In a study by Cruciani et al. [115], patients affected by cancer with carnitine deficiency-induced fatigue received L-carnitine ( $3000 \mathrm{mg} /$ day) for a week, and showed a significant improvement, enhancing total and free carnitine without any toxicity or complications. Use of L-carnitine (4 g/day) for three months in patients with advanced pancreatic cancer improved quality of life and nutritional status [116]. 
In a study by Shirali et al. [117], male teen soccer players received carnitine ( $2 \mathrm{~g} /$ day $)$ combined with caffeine $(6 \mathrm{mg} / \mathrm{kg} /$ day $)$ and showed a reduction in body weight and body fat percentage by increasing lipolysis. Use of L-carnitine $(250 \mathrm{mg})$ for 12 weeks in patients with polycystic ovary syndrome reduced hip and waist circumference, body mass index, and weight [118]. In a study conducted in Libia by Ibrahim et al., 1000-mg L-carnitine supplementation twice a day for three months in type 2 diabetic patients with dyslipidemia reduced triglyceride levels, but did not change low-density lipoprotein-cholesterol, high-density cholesterol lipoprotein or total cholesterol levels [119].

Moradi et al. [120] improved idiopathic male infertility through the administration of clomiphene citrate and carnitine, so that their patients receiving carnitine $(25 \mathrm{mg} /$ day) showed an increase in semen volume and those receiving clomiphene citrate $(2 \mathrm{~g} /$ day $)$ showed an improvement in morphology and motility. In another study, patients with chronic hepatitis $C$ virus infection who received L-carnitine ( $2 \mathrm{~g}$ twice a day) combined with ribavirin ( $800 \mathrm{mg} /$ day) for 12 months showed an improvement in sustained virological response and modulation of thrombocytopoiesis, leucopoiesis and erythropoiesis [121]. The use of L-carnitine $(50 \mathrm{mg} / \mathrm{kg} / \mathrm{day})$ in patients with maple syrup urine disease for two months diminished DNA damage index [122].

\section{Carnitine-Based Dietary Supplements}

Nowadays, food supplements field is certainly varied and growing: a great range of new products are launched on the market every year. This is reflected in a new reorganization of drugs leading to changes in dietary supplement regulations [123-136]. Dietary supplements are made by mixing biologically active substances intended for consumption with food or as an addition to food products, with the purpose of optimizing metabolic processes and human body functions. Dietary supplements include, mainly, micronutrients, e.g., vitamins, trace elements, amino acids and enzymes, but also proteins, probiotics and oils, which can provide antioxidant, detoxifying, immunomodulatory and adaptogenic effects, etc.

Virji, in a 2017 study [137], remarked on the potential benefits of L-carnitine as dietary supplement. There is a growing body of outcomes data that demonstrates the beneficial effects of $\mathrm{L}$-carnitine in the treatment of coronary artery disease, metabolic syndrome, and obesity. Odle et al., in 2014, reported how the L-isomer can be synthesized, and, consequently, high-purity dietary supplements are commercially available and are generally recognized as safe [14].

\subsection{Monitoring L-Carnitine in Dietary Supplements}

In the context of dietary supplements, detection of physiologically active components represents a difficult task and requires the use of modern highly informative research methods. Some studies describing this methodological approach to L-carnitine in dietary supplements are reported in the following. De Andrés et al. [138] proposed achiral liquid chromatography with circular dichroism detection for the determination of carnitine enantiomers in dietary supplements and pharmaceutical formulations [138]. Sánchez-Hernández et al. [139] developed a method for simultaneous and simple unequivocal identification and determination of carnitine enantiomers in dietary food supplements by capillary electrophoresis-electrospray ionization-tandem mass spectrometry [139]. Isaguirre et al. [140] proposed a new flow injection method for quality control of dietary supplements containing L-carnitine using an extraction mediated by sodium taurodeoxycholate coacervate coupled to molecular fluorescence [140]. A recent work of Voitiuk et al. [141] proposed a simple, rapid and selective method for determining ascorbic acid and L-carnitine L-tartrate in a multicomponent dietary supplement, produced in the form of sachets, using HPLC with spectrophotometric detection [141]. Ellingson et al. used LC-MS/MS-based analysis to measure total and free carnitine levels, so that acid-assisted microwave hydrolysis and water extraction were employed to analyze total and free analysis respectively. Their results showed overall RSD with intermediate precision of $3.1 \%$ and $3.3 \%$ and an overall repeatability of $2.7 \%$ and $2.9 \%$ for total and free carnitine levels, respectively [142]. Johnson et al. applied LC-MS/MS analysis to measure the plasma levels of total and free carnitine. 
Acetonitrile $0.3 \%$ formic acid was used to extract the total carnitine and to avoid the time-consuming step of salt elimination, and acid hydrolysis was utilized instead of base hydrolysis to quantify the total carnitine level [143]. The LOQ and LOD values were 2.54 and $1.79 \mu \mathrm{mol} / \mathrm{L}$ for the total carnitine and 1.36 and $0.87 \mu \mathrm{mol} / \mathrm{L}$ for the free carnitine. The varying analytical techniques used seem to indicate that the monitoring can be achieved by using different techniques but also that more in-depth studies are needed to identify a unique method of analysis which can guarantee efficient monitoring of the amount of the active components present in a food supplement.

\subsection{A Shot of Dietary Supplement Label Databases}

Considering the relevance of dietary supplements in the evaluation of total dietary intake, remarked on during the National Health and Nutrition Examination Survey (NHANES), a dietary supplement label database [144,145] was launched in 2013 by the Academy of Nutrition and Dietetics in the United States: this contains label information (brand name, ingredients, amount per serving, and manufacturer contact information) on more than 71,000 dietary supplements present and consumed in the U.S. marketplace [144,146-148]. The dietary supplement label database (DSLD) can be used to track changes in product composition and capture new products entering the market, representing a useful tool for consumers, professionals, and researchers, useful for multiple applications [144,147]. For example, by searching in DSLD [146] by product/brand name, and typing "carnitine" as a keyword, research has identified 434 products.

Recently, at European level, information on the compositions reported on labels of selected dietary supplements has been collected and updated for the development of a DSLD according to products' availability on the Italian market, also including items consumed in the last Italian Dietary Survey [149,150]: a total of 558 products have been entered into the database as of December 2019. This aims to give a uniform image and representation of the major classes of food supplements consumed in Italy. It is important to underline that, for each item, a code was assigned following the food classification system FoodEx2 developed by EFSA [151], to allow standardization and harmonization of the data among different countries.

In particular, DSLD in Italy reported the codes for seven carnitine-based products, classifying, with a base term [A03SC] Carnitine or creatine-based supplement for sports people. Carnitine is also present as an ingredient in Mixed supplements/formulations [A03TC] as well as in Micronutrients supplement for sports people [A03SB] groups.

\section{Conclusions and Future Remarks}

This perspective paper offers an updated overview of the nutraceutical value of carnitine and its use in dietary supplements. The beneficial health effects observed are many.

Nonetheless, the use of carnitine as dietary supplement should be regulated to avoid overdosage. Some studies show a possible onset of side effects related to carnitine supplements. These unwanted effects include sporadic vomiting and diarrhea, as observed in children with autism spectrum disorder when administered high doses of carnitine, e.g., $400 \mathrm{mg} / \mathrm{kg} /$ day [152]. The recent review by Malaguarnera and Cauli [153], summarizing the effects of L-carnitine in patients with autism spectrum disorders, reported that doses of about $50-100 \mathrm{mg} / \mathrm{kg} /$ day are generally well tolerated, whereas side effects observed with a dose of $200 \mathrm{mg} / \mathrm{kg} /$ day resulted in gastro-intestinal symptoms and a strong, unpleasant skin odor. On the other hand, a recent meta-analysis published by Asadi et al. [154] showed that L-carnitine supplementation could be effective in maintaining lipid profile levels, particularly in doses higher than $1500 \mathrm{mg} /$ day, even if more RCTs with large sample sizes, focusing on gut microbiome profiles and dietary patterns, are needed. The limited number of clinical trials evaluating the effects of carnitine the human health seems to emphasize the need for and importance of further research in this field. 
Author Contributions: A.D. and A.S. conceived and designed the work. A.D., M.L., A.N., E.B.S. and A.S. wrote the work. A.N., S.B.S., A.M.S., M.L., and P.S. validated and elaborated data information and figures. A.D., M.L., A.N., S.S., A.M.S., P.S., E.B.S., and A.S. made a substantial contribution to the revision of work and approved it for publication. All authors have read and agreed to the published version of the manuscript.

Funding: The authors acknowledge the support of the research project: Nutraceutica come supporto nutrizionale nel paziente oncologico, CUP: B83D18000140007. E. B. Souto acknowledges the sponsorship of the projects M-ERA-NET-0004/2015-PAIRED and UIDB/04469/2020 (strategic fund), A.M.S. the UID/AGR/04033/2019 (CITAB), receiving support from the Portuguese Science and Technology Foundation, Ministry of Science and Education (FCT/MEC) through national funds, and co-financed by FEDER, under the Partnership Agreement PT2020.

Conflicts of Interest: The authors declare no conflict of interest.

\section{References}

1. Alesci, S. Carnitine: The science behind a conditionally essential nutrient. Ann. N. Y. Acad. Sci. 2004, 1033, 1-197.

2. Wolf, G. The discovery of a vitamin role for carnitine: The first 50 years. J. Nutr. 2006, 136, 2131-2134. [CrossRef] [PubMed]

3. Sharma, S.; Black, S.M. Carnitine homeostasis, mitochondrial function and cardiovascular disease. Drug Discov. Today 2009, 6, e31-e39. [CrossRef] [PubMed]

4. Marcovina, S.M.; Sirtori, C.; Peracino, A.; Gheorghiade, M.; Borum, P.; Remuzzi, G.; Ardehali, H. Translating the basic knowledge of mitochondrial functions to metabolic therapy: Role of L-carnitine. Transl. Res. 2013, 161, 73-84. [CrossRef]

5. El-Hattab, A.W.; Scaglia, F. Disorders of carnitine biosynthesis and transport. Mol. Genet. Metab. 2015, 116, 107-112. [CrossRef]

6. Longo, N.; Amat di San Filippo, C.; Pasquali, M. Disorders of carnitine transport and the carnitine cycle. Am. J. Med. Genet. 2006, 142, 77-85. [CrossRef]

7. Wang, L.Y.; Chen, N.I.; Chen, P.W.; Chiang, S.C.; Hwu, W.L.; Lee, N.C.; Chien, Y.H. Newborn screening for citrin deficiency and carnitine uptake defect using second-tier molecular tests. BMC Med. Genet. 2013, 14, 24. [CrossRef]

8. Chen, Y.C.; Chien, Y.H.; Chen, P.W.; Leung-Sang Tang, N.; Chiu, P.C.; Hwu, W.L.; Lee, N.C. Carnitine uptake defect (primary carnitine deficiency): Risk in genotype-phenotype correlation. Hum. Mutat. 2013, 34, 655. [CrossRef]

9. Lee, N.C.; Tang, N.L.S.; Chien, Y.H.; Chen, C.A.; Lin, S.J.; Chiu, P.C.; Huang, A.C.; Hwu, W.L. Diagnoses of newborns and mothers with carnitine uptake defects through newborn screening. Mol. Genet. Metabol. 2010, 100, 46-50. [CrossRef]

10. Longo, N.; Frigeni, M.; Pasquali, M. Carnitine transport and fatty acid oxidation. Biochem. Biophys. Acta 2016, 1863, 2422-2435. [CrossRef]

11. Steiber, A.; Kerner, J.; Hoppel, C.L. Carnitine: A nutritional, biosynthetic, and functional perspective. Mol. Aspects Med. 2004, 25, 455-473. [CrossRef] [PubMed]

12. Reuter, S.E.; Evans, A.M. Carnitine and acylcarnitines. Clin. Pharmacokin. 2012, 51, 553-572. [CrossRef] [PubMed]

13. Pormsila, W.; Krähenbühl, S.; Hauser, P.C. Determination of carnitine in food and food supplements by capillary electrophoresis with contactless conductivity detection. Electrophoresis 2010, 31, 2186-2191. [CrossRef] [PubMed]

14. Odle, J.; Adams, S.H.; Vockley, J. Carnitine. Adv. Nutr. 2014, 5, 289-290. [CrossRef] [PubMed]

15. Flanagan, J.L.; Simmons, P.A.; Vehige, J.; Willcox, M.D.; Garrett, Q. Role of carnitine in disease. Nutr. Metabol. 2010, 7, 30. [CrossRef]

16. Ribas, G.S.; Vargas, C.R.; Wajner, M. L-carnitine supplementation as a potential antioxidant therapy for inherited neurometabolic disorders. Gene 2014, 533, 469-476. [CrossRef]

17. Xu, Y.; Jiang, W.; Chen, G.; Zhu, W.; Ding, W.; Ge, Z.; Tan, Y.; Ma, T.; Cui, G. L-carnitine treatment of insulin resistance: A systematic review and meta-analysis. Adv. Clin. Exper. Med. 2017, 26, 333-338. [CrossRef]

18. DiNicolantonio, J.J.; Lavie, C.J.; Fares, H.; Menezes, A.R.; O’Keefe, J.H. L-carnitine in the secondary prevention of cardiovascular disease: Systematic review and meta-analysis. Proc. Mayo Clin. Proc. 2013, 88, 544-551. [CrossRef] 
19. Shang, R.; Sun, Z.; Li, H. Effective dosing of L-carnitine in the secondary prevention of cardiovascular disease: A systematic review and meta-analysis. BMC Cardiovasc Disord. 2014, 14, 88. [CrossRef]

20. Melone, M.A.B.; Valentino, A.; Margarucci, S.; Galderisi, U.; Giordano, A.; Peluso, G. The carnitine system and cancer metabolic plasticity. Cell Death Dis. 2018, 9, 1-12. [CrossRef]

21. Hathcock, J.N.; Shao, A. Risk assessment for carnitine. Regul. Toxicol. Pharmacol. 2006, 46, 23-28. [CrossRef] [PubMed]

22. Ribas, G.S.; Manfredini, V.; de Marco, M.G.; Vieira, R.B.; Wayhs, C.Y.; Vanzin, C.S.; Biancini, G.B.; Wajner, M.; Vargas, C.R. Prevention by L-carnitine of DNA damage induced by propionic and L-methylmalonic acids in human peripheral leukocytes in vitro. Mutat. Res. Genet Toxicol. Environ. Mutagen. 2010, 702, 123-128. [CrossRef] [PubMed]

23. Banihani, S.; Sharma, R.; Bayachou, M.; Sabanegh, E.; Agarwal, A. Human sperm DNA oxidation, motility and viability in the presence of L-carnitine during in vitro incubation and centrifugation. Andrologia 2012, 44, 505-512. [CrossRef] [PubMed]

24. Zamani, E.; Shokrzadeh, M.; Modanloo, M.; Shaki, F. In Vitro Study Towards Role of Acrylamide-Induced Genotoxicity in Human Lymphocytes and the Protective Effect of L-carnitine. Braz Arch Bio Technol. 2018, 61. [CrossRef]

25. Hua, X.; Deng, R.; Li, J.; Chi, W.; Su, Z.; Lin, J.; Pflugfelder, S.C.; Li, D.-Q. Protective effects of L-carnitine against oxidative injury by hyperosmolarity in human corneal epithelial cells. Investig. Ophthal. Visual Sci. 2015, 56, 5503-5511. [CrossRef]

26. Farahzadi, R.; Fathi, E.; Mesbah-Namin, S.A.; Zarghami, N. Anti-aging protective effect of L-carnitine as clinical agent in regenerative medicine through increasing telomerase activity and change in the hTERT promoter CpG island methylation status of adipose tissue-derived mesenchymal stem cells. Tissue Cell. 2018, 54, 105-113. [CrossRef]

27. Nakamura, Y.; Iida, H.; Nakatake, R.; Sakaguchi, T.; Kaibori, M.; Okumura, T.; Hamada, Y.; Doi, T. L-carnitine has a liver-protective effect through inhibition of inducible nitric oxide synthase induction in primary cultured rat hepatocytes. Funct. Foods Health Dis. 2018, 8, 212-227. [CrossRef]

28. Baci, D.; Bruno, A.; Bassani, B.; Tramacere, M.; Mortara, L.; Albini, A.; Noonan, D.M. Acetyl-L-carnitine is an anti-angiogenic agent targeting the VEGFR2 and CXCR4 pathways. Cancer Lett. 2018, 429, 100-116. [CrossRef]

29. Fernandes, S.; Salta, S.; Bravo, J.; Silva, A.; Summavielle, T. Acetyl-L-carnitine prevents methamphetamineinduced structural damage on endothelial cells via ILK-related MMP-9 activity. Mol. Neurobiol. 2016, 53, 408-422. [CrossRef]

30. Singh, M.; Miura, P.; Renden, R. Age-related defects in short-term plasticity are reversed by acetyl-L-carnitine at the mouse calyx of Held. Neurobiol. Aging. 2018, 67, 108-119. [CrossRef]

31. Nicassio, L.; Fracasso, F.; Sirago, G.; Musicco, C.; Picca, A.; Marzetti, E.; Calvani, R.; Cantatore, P.; Gadaleta, M.N.; Pesce, V. Dietary supplementation with acetyl-L-carnitine counteracts age-related alterations of mitochondrial biogenesis, dynamics and antioxidant defenses in brain of old rats. Exp. Gerontol. 2017, 98, 99-109. [CrossRef] [PubMed]

32. Muoio, D.M.; Noland, R.C.; Kovalik, J.P.; Seiler, S.E.; Davies, M.N.; DeBalsi, K.L.; Ilkayeva, O.R.; Stevens, R.D.; Kheterpal, I.; Zhang, J. Muscle-specific deletion of carnitine acetyltransferase compromises glucose tolerance and metabolic flexibility. Cell Metabol. 2012, 15, 764-777. [CrossRef] [PubMed]

33. Abdelkarem, H.M.; Fadda, L.H.; Hassan, A.A. Potential intervention of $\alpha$-Lipoic acid and carnitine on insulin sensitivity and anti-inflammatory cytokines levels in fructose-fed rats, a model of metabolic syndrome. J. Diet. Suppl. 2017, 14, 54-64. [CrossRef] [PubMed]

34. Bodaghi-Namileh, V.; Sepand, M.R.; Omidi, A.; Aghsami, M.; Seyednejad, S.A.; Kasirzadeh, S.; Sabzevari, O. Acetyl-L-carnitine attenuates arsenic-induced liver injury by abrogation of mitochondrial dysfunction, inflammation, and apoptosis in rats. Environ. Toxicol. Pharmacol. 2018, 58, 11-20. [CrossRef] [PubMed]

35. Edres, H.A.; Taha, N.M.; Mandour, A.E.W.A.; Lebda, M.A. Impact of L-carnitine on Bisphenol A-Induced Kidney Damage in Rats. Alex. J. Vet. Sci. 2018, 56, 11-17. [CrossRef]

36. Al-Eisa, R.A.; Al-Salmi, F.A.; Hamza, R.Z.; El-Shenawy, N.S. Role of L-carnitine in protection against the cardiac oxidative stress induced by aspartame in Wistar albino rats. PLoS ONE 2018, 13, e0204913. [CrossRef] [PubMed] 
37. Couturier, A.; Ringseis, R.; Mooren, F.C.; Krüger, K.; Most, E.; Eder, K. Carnitine supplementation to obese Zucker rats prevents obesity-induced type I to type II muscle fiber transition and favors an oxidative phenotype of skeletal muscle. Nutr. Metab. 2013, 10, 48. [CrossRef]

38. Ahmed, M.M.; Ibrahim, Z.S.; Alkafafy, M.; El-Shazly, S.A. L-carnitine protects against testicular dysfunction caused by gamma irradiation in mice. Acta histochemica 2014, 116, 1046-1055. [CrossRef]

39. Kim, J.H.; Pan, J.H.; Lee, E.S.; Kim, Y.J. L-carnitine enhances exercise endurance capacity by promoting muscle oxidative metabolism in mice. Biochem. Biophys. Res. Commun. 2015, 464, 568-573. [CrossRef]

40. Meky, N.H.; Haggag, A.M.; Kamal, A.M.; Ahmed, Z.A. The Protective Effect of L-carnitine against Gamma Irradiation-Induced Cardiotoxicity in Male Albino Rats. Egypt. Acad. J. Bio. Sci. Phys. Mol. Bio. 2017, 9, 9-20. [CrossRef]

41. Sepand, M.R.; Razavi-Azarkhiavi, K.; Omidi, A.; Zirak, M.R.; Sabzevari, S.; Kazemi, A.R.; Sabzevari, O. Effect of acetyl-L-carnitine on antioxidant status, lipid peroxidation, and oxidative damage of arsenic in rat. Biol. Trace Elem. Res. 2016, 171, 107-115. [CrossRef] [PubMed]

42. Jang, J.; Park, J.; Chang, H.; Lim, K. L-carnitine supplement reduces skeletal muscle atrophy induced by prolonged hindlimb suspension in rats. Appl. Physiol. Nutr. Metab. 2016, 41, 1240-1247. [CrossRef] [PubMed]

43. Collins, H.L.; Drazul-Schrader, D.; Sulpizio, A.C.; Koster, P.D.; Williamson, Y.; Adelman, S.J.; Owen, K.; Sanli, T.; Bellamine, A. L-carnitine intake and high trimethylamine $\mathrm{N}$-oxide plasma levels correlate with low aortic lesions in ApoE ${ }^{-/-}$transgenic mice expressing CETP. Atherosclerosis 2016, 244, 29-37. [CrossRef] [PubMed]

44. Canbolat, E.P.; Sagsoz, N.; Noyan, V.; Yucel, A.; Kisa, U. Effects of L-carnitine on oxidative stress parameters in oophorectomized rats. Alex. Med. J. 2017, 53, 55-60. [CrossRef]

45. Zamani, E.; Shokrzadeh, M.; Ziar, A.; Abedian-Kenari, S.; Shaki, F. Acrylamide attenuated immune tissues' function via induction of apoptosis and oxidative stress: Protection by L-carnitine. Hum. Exp. Toxicol. 2018, 37, 859-869. [CrossRef]

46. Zakzok, F.B.; Hegazy, H.M.; Yosef, T.A.; Gomaa, G.M. Mitigating impact of L-carnitine against dimethoate induction of hepatic and testicular genotoxicity in rats: The role of oxidative stress. Toxin Rev. 2018. [CrossRef]

47. Salama, S.A.; Arab, H.H.; Omar, H.A.; Gad, H.S.; Abd-Allah, G.M.; Maghrabi, I.A. L-carnitine mitigates UVA-induced skin tissue injury in rats through downregulation of oxidative stress, p38/c-Fos signaling, and the proinflammatory cytokines. Chem.-Biol. Interact. 2018, 285, 40-47. [CrossRef]

48. Cruz, W.M.S.; Guimaraes, S.; Maciel, G.C.; Huguenin, A.B.A.; Carvalho, M.E.D.; Costa, B.O.; Silva, G.A.; Colafranceschi, A.S.; Scalco, F.B.; Ribeiro, M. L-carnitine supplementation in the recovery of plasma L-carnitine in patients with heart failure submitted to coronary artery bypass grafting. Anais da Acad. Bras. de Ciências 2018, 90, 3099-3104. [CrossRef]

49. Yaghubi, E.; Daneshpazhooh, M.; Djalali, M.; Mohammadi, H.; Sepandar, F.; Fakhri, Z.; Ghaedi, E.; Keshavarz, S.A.; Balighi, K.; Mahmoudi, H. Effects of L-carnitine supplementation on cardiovascular and bone turnover markers in patients with pemphigus vulgaris under corticosteroids treatment: A randomized, double-blind, controlled trial. Dermat. Therap. 2019, 32, e13049. [CrossRef]

50. Talari, H.R.; Azad, Z.J.; Hamidian, Y.; Samimi, M.; Gilasi, H.R.; Afshar, F.E.; Ostadmohammadi, V.; Asemi, Z. Effects of carnitine administration on carotid intima-media thickness and inflammatory factors in patients with polycystic ovary syndrome: A randomized, double-blind, placebo-controlled trial. Int. J. Prev. Med. 2019, 10, 89.

51. Ravikumar, S.; Prabhu, S.; Vani, R. Effects of L-carnitine on the erythrocytes of stored human blood. Transfus. Med. 2019, 8. [CrossRef] [PubMed]

52. Mohammadi, M.; Talasaz, A.H.; Alidoosti, M. Preventive effect of L-carnitine and its derivatives on endothelial dysfunction and platelet aggregation. Clin. Nutr. ESPEN 2016, 15, 1-10. [CrossRef] [PubMed]

53. Guerreiro, G.; Faverzani, J.; Jacques, C.E.D.; Marchetti, D.P.; Sitta, A.; de Moura Coelho, D.; Kayser, A.; Kok, F.; Athayde, L.; Manfredini, V. Oxidative damage in glutaric aciduria type I patients and the protective effects of 1-carnitine treatment. J. Cell. Biochem. 2018, 119, 10021-10032. [CrossRef] [PubMed]

54. Gnoni, A.; Longo, S.; Gnoni, G.V.; Giudetti, A.M. Carnitine in Human Muscle Bioenergetics: Can Carnitine Supplementation Improve Physical Exercise? Molecules 2020, 25, 182. [CrossRef] [PubMed] 
55. Kitano, Y.; Hashimoto, S.; Matsumoto, H.; Yamochi, T.; Yamanaka, M.; Nakaoka, Y.; Fukuda, A.; Inoue, M.; Ikeda, T.; Morimoto, Y. Oral administration of L-carnitine improves the clinical outcome of fertility in patients with IVF treatment. Gynecol. Endocr. 2018, 34, 684-688. [CrossRef] [PubMed]

56. Verrina, E.; Caruso, U.; Calevo, M.G.; Emma, F.; Sorino, P.; De Palo, T.; Lavoratti, G.; Dertenois, L.T.; Cassanello, M.; Cerone, R. Effect of carnitine supplementation on lipid profile and anemia in children on chronic dialysis. Ped. Neph. 2007, 22, 727-733. [CrossRef]

57. Geier, D.A.; Kern, J.K.; Davis, G.; King, P.G.; Adams, J.B.; Young, J.L.; Geier, M.R. A prospective double-blind, randomized clinical trial of levocarnitine to treat autism spectrum disorders. Med. Sci. Monit. 2011, 17, PI15. [CrossRef]

58. Fahmy, S.F.; El-hamamsy, M.H.; Zaki, O.K.; Badary, O.A. L-carnitine supplementation improves the behavioral symptoms in autistic children. Res. Autism Spect. Disord. 2013, 7, 159-166. [CrossRef]

59. Ziats, M.N.; Comeaux, M.S.; Yang, Y.; Scaglia, F.; Elsea, S.H.; Sun, Q.; Beaudet, A.L.; Schaaf, C.P. Improvement of regressive autism symptoms in a child with TMLHE deficiency following carnitine supplementation. Am. J. Med. Genet. A. 2015, 167, 2162-2167. [CrossRef]

60. Roy, M.J.; Dionne, S.; Marx, G.; Qureshi, I.; Sarma, D.; Levy, E.; Seidman, E.G. In vitro studies on the inhibition of colon cancer by butyrate and carnitine. Nutrition 2009, 25, 1193-1201. [CrossRef]

61. Baci, D.; Bruno, A.; Cascini, C.; Gallazzi, M.; Mortara, L.; Sessa, F.; Pelosi, G.; Albini, A.; Noonan, D.M. Acetyl-L-carnitine downregulates invasion (CXCR4/CXCL12, MMP-9) and angiogenesis (VEGF, CXCL8) pathways in prostate cancer cells: Rationale for prevention and interception strategies. J. Exp. Clin. Cancer Res. 2019, 38, 464. [CrossRef] [PubMed]

62. Huang, H.; Liu, N.; Guo, H.; Liao, S.; Li, X.; Yang, C.; Liu, S.; Song, W.; Liu, C.; Guan, L. L-carnitine is an endogenous HDAC inhibitor selectively inhibiting cancer cell growth in vivo and in vitro. PLoS ONE 2012, 7, e49062. [CrossRef] [PubMed]

63. Zhang, R.; Zhang, H.; Zhang, Z.; Wang, T.; Niu, J.; Cui, D.; Xu, S. Neuroprotective effects of pre-treatment with L-carnitine and acetyl-L-carnitine on ischemic injury in vivo and in vitro. Int. J. Mol. Sci. 2012, 13, 2078-2090. [CrossRef] [PubMed]

64. Deon, M.; Landgraf, S.S.; Lamberty, J.F.; Moura, D.J.; Saffi, J.; Wajner, M.; Vargas, C.R. Protective effect of L-carnitine on Phenylalanine-induced DNA damage. Metab. Brain Dis. 2015, 30, 925-933. [CrossRef]

65. Kocsis, K.; Frank, R.; Szabó, J.; Knapp, L.; Kis, Z.; Farkas, T.; Vécsei, L.; Toldi, J. Acetyl-L-carnitine restores synaptic transmission and enhances the inducibility of stable LTP after oxygen-glucose deprivation. Neuroscience 2016, 332, 203-211. [CrossRef]

66. Bavari, M.; Tabandeh, M.R.; Najafzadeh Varzi, H.; Bahramzadeh, S. Neuroprotective, antiapoptotic and antioxidant effects of L-carnitine against caffeine-induced neurotoxicity in SH-SY5Y neuroblastoma cell line. Drug Chem. Toxicol. 2016, 39, 157-166. [CrossRef]

67. de Moraes, M.S.; Guerreiro, G.; Sitta, A.; de Moura Coelho, D.; Manfredini, V.; Wajner, M.; Vargas, C.R. Oxidative damage in mitochondrial fatty acids oxidation disorders patients and the in vitro effect of L-carnitine on DNA damage induced by the accumulated metabolites. Arch. Biochem. Biophys. 2020, 679, 108206. [CrossRef]

68. Montesano, A.; Senesi, P.; Vacante, F.; Mollica, G.; Benedini, S.; Mariotti, M.; Luzi, L.; Terruzzi, I. $\mathrm{L}$-carnitine counteracts in vitro fructose-induced hepatic steatosis through targeting oxidative stress markers. J. Endocrinol. Investig. 2019, 43, 493-503. [CrossRef]

69. Terruzzi, I.; Montesano, A.; Senesi, P.; Villa, I.; Ferraretto, A.; Bottani, M.; Vacante, F.; Spinello, A.; Bolamperti, S.; Luzi, L. L-carnitine reduces oxidative stress and promotes cells differentiation and bone matrix proteins expression in human osteoblast-like cells. BioMed. Res. Int. 2019, 2019, 5678548. [CrossRef]

70. Calandrella, N.; De Seta, C.; Scarsella, G.; Risuleo, G. Carnitine reduces the lipoperoxidative damage of the membrane and apoptosis after induction of cell stress in experimental glaucoma. Cell Death Dis. 2010, 1, e62. [CrossRef]

71. Farahzadi, R.; Mesbah-Namin, S.A.; Zarghami, N.; Fathi, E. L-carnitine effectively induces hTERT gene expression of human adipose tissue-derived mesenchymal stem cells obtained from the aged subjects. Int. J. Stem Cells. 2016, 9, 107. [CrossRef] [PubMed] 
72. Rodrigues, D.G.B.; de Moura Coelho, D.; Sitta, Â.; Jacques, C.E.D.; Hauschild, T.; Manfredini, V.; Bakkali, A.; Struys, E.A.; Jakobs, C.; Wajner, M. Experimental evidence of oxidative stress in patients with 1-2-hydroxyglutaric aciduria and that L-carnitine attenuates in vitro DNA damage caused by d-2-hydroxyglutaric and 1-2-hydroxyglutaric acids. Toxicol. Vitro 2017, 42, 47-53. [CrossRef] [PubMed]

73. Le Borgne, F.; Ravaut, G.; Bernard, A.; Demarquoy, J. L-carnitine protects C2C12 cells against mitochondrial superoxide overproduction and cell death. World J. Biol. Chem. 2017, 8, 86. [CrossRef] [PubMed]

74. Al-Shammari, M.H.M.; Yenzeel, J.H.; Fakhrildin, M.-B.M. Effect of L-carnitine and COQ10 addition to SMART Pro-medium on human sperm concentration, sperm morphology and chromatin structure during in vitro sperm activation. J. Pharm. Bio. Sci. 2017, 12, 51-55.

75. Abdel-Emam, R.A.; Ahmed, E.A.; Ali, M.F. The protective role of L-carnitine against 1st- and 2nd-generation antihistamine-induced liver injury in mice. Compar. Clin. Path. 2020, 29, 213-221. [CrossRef]

76. Ahmed, E.A.; Abd-Eldayem, A.M.; Aboulhagag, N.A. The possible protective effects of vitamin D and L-carnitine against used atorvastatin-induced myopathy and hepatotoxicity. Compar. Clin. Path. 2019, 28, 1751-1759. [CrossRef]

77. Salic, K.; Gart, E.; Seidel, F.; Verschuren, L.; Caspers, M.; van Duyvenvoorde, W.; Wong, K.E.; Keijer, J.; Bobeldijk-Pastorova, I.; Wielinga, P.Y. Combined Treatment with L-carnitine and Nicotinamide Riboside Improves Hepatic Metabolism and Attenuates Obesity and Liver Steatosis. Int. J. Mol. Sci. 2019, 20, 4359. [CrossRef]

78. Ali, S.A.; Faddah, L.; Abdel-Baky, A.; Bayoumi, A. Protective effect of L-carnitine and coenzyme Q10 on CCl4-induced liver injury in rats. Sci. Pharm. 2010, 78, 881-896. [CrossRef]

79. Dobrzyńska, I.; Szachowicz-Petelska, B.; Skrzydlewska, E.; Figaszewski, Z. Effect of L-carnitine on liver cell membranes in ethanol-intoxicated rats. Chem.-Bio. Interact. 2010, 188, 44-51. [CrossRef]

80. Xiang, Y.; Piao, S.; Zou, H.; Jin, J.; Fang, M.; Lei, D.; Gao, B.; Yang, C.; Li, C. L-carnitine protects against cyclosporine-induced pancreatic and renal injury in rats. Transpl. Proc. 2013, 45, 3127-3134. [CrossRef]

81. Ishikawa, H.; Takaki, A.; Tsuzaki, R.; Yasunaka, T.; Koike, K.; Shimomura, Y.; Seki, H.; Matsushita, H.; Miyake, Y.; Ikeda, F. L-carnitine prevents progression of non-alcoholic steatohepatitis in a mouse model with upregulation of mitochondrial pathway. PLOS ONE 2014, 9, e100627. [CrossRef] [PubMed]

82. Wang, S.; Xu, J.; Zheng, J.; Zhang, X.; Shao, J.; Zhao, L.; Hao, J. Anti-Inflammatory and Antioxidant Effects of Acetyl-L-carnitine on Atherosclerotic Rats. Med. Sci. Monit. 2020, 26, e920250. [CrossRef] [PubMed]

83. Blanca, A.J.; Ruiz-Armenta, M.V.; Zambrano, S.; Miguel-Carrasco, J.L.; Arias, J.L.; Arevalo, M.; Mate, A.; Aramburu, O.; Vazquez, C.M. Inflammatory and fibrotic processes are involved in the cardiotoxic effect of sunitinib: Protective role of L-carnitine. Toxicol. Lett. 2016, 241, 9-18. [CrossRef] [PubMed]

84. Aziz, M.; Abd El Fattah, M.A.; Ahmed, K.A.; Moawad, H. Protective effects of Olmesartan and L-carnitine on doxorubicin-induced Cardiotoxicity in rats. Can. J. Physiol. Pharmacol. 2019, 999, 183-193. [CrossRef] [PubMed]

85. Lapi, D.; Sabatino, L.; Altobelli, G.G.; Mondola, P.; Cimini, V.; Colantuoni, A. Effects of propionyl-L-carnitine on ischemia-reperfusion injury in hamster cheek pouch microcirculation. Front. Physiol. 2010, 1, 132. [CrossRef] [PubMed]

86. Omori, Y.; Ohtani, T.; Sakata, Y.; Mano, T.; Takeda, Y.; Tamaki, S.; Tsukamoto, Y.; Kamimura, D.; Aizawa, Y.; Miwa, T. L-carnitine prevents the development of ventricular fibrosis and heart failure with preserved ejection fraction in hypertensive heart disease. J. Hypertens. 2012, 30, 1834-1844. [CrossRef]

87. Zambrano, S.; Blanca, A.J.; Ruiz-Armenta, M.V.; Miguel-Carrasco, J.L.; Arévalo, M.; Vázquez, M.J.; Mate, A.; Vázquez, C.M. L-carnitine protects against arterial hypertension-related cardiac fibrosis through modulation of PPAR- $\gamma$ expression. Biochem. Pharmacol. 2013, 85, 937-944. [CrossRef]

88. Alharthi, W.A.; Hamza, R.Z.; Elmahdi, M.M.; Abuelzahab, H.S.H.; Saleh, H. Selenium and L-carnitine Ameliorate Reproductive Toxicity Induced by Cadmium in Male Mice. Biol. Trace Elem. Res. 2019. [CrossRef]

89. Kelek, S.E.; Afşar, E.; Akçay, G.; Danışman, B.; Aslan, M. Effect of chronic L-carnitine supplementation on carnitine levels, oxidative stress and apoptotic markers in peripheral organs of adult Wistar rats. Food Chem. Toxicol. 2019, 134, 110851. [CrossRef]

90. Dokmeci, D.; Inan, M.; Basaran, U.N.; Yalcin, O.; Aydogdu, N.; Turan, F.N.; Uz, Y.H. Protective effect of L-carnitine on testicular ischaemia-reperfusion injury in rats. Cell Biochem. Funct. Cellul. 2007, 25, 611-618. [CrossRef] 
91. Boyacioglu, M.; Turgut, H.; Akgullu, C.; Eryilmaz, U.; Kum, C.; Onbasili, O.A. The efficient of L-carnitine on oxidative stress responses of experimental contrast-induced nephropathy in rat. J. Vet. Med. Sci. 2014, 76, 13-0202. [CrossRef] [PubMed]

92. Abd-Elrazek, A.M.; Ahmed-Farid, O.A.H. Protective effect of L-carnitine and L-arginine against busulfan-induced oligospermia in adult rat. Andrologia 2018, 50. [CrossRef] [PubMed]

93. Masoumi-Ardakani, Y.; Aminizadeh, S.; Fallah, H.; Shahouzehi, B. L-carnitine different doses affect serum and pancreas tissue Antioxidative defense and histopathology in STZ-induced diabetic rats. Biologia 2020. [CrossRef]

94. Hooshmand, S.; Balakrishnan, A.; Clark, R.M.; Owen, K.Q.; Koo, S.I.; Arjmandi, B.H. Dietary L-carnitine supplementation improves bone mineral density by suppressing bone turnover in aged ovariectomized rats. Phytomedicine 2008, 15, 595-601. [CrossRef] [PubMed]

95. Yuan, J.; Jiang, Q.; Song, L.; Liu, Y.; Li, M.; Lin, Q.; Li, Y.; Su, K.; Ma, Z.; Wang, Y.; et al. L-carnitine Is Involved in Hyperbaric Oxygen-Mediated Therapeutic Effects in High Fat Diet-Induced Lipid Metabolism Dysfunction. Molecules 2020, 25, 176. [CrossRef] [PubMed]

96. Chidiebere, U.; Ambali, S.F.; Ayo, J.O.; Eseivo, K.A. Acetyl-L-carnitine attenuates haemotoxicity induced by subacute chlorpyrifos exposure in Wistar rats. Der. Pharm. Lettre. 2011, 3, 292-303.

97. Yarizadh, H.; Shab-Bidar, S.; Zamani, B.; Vanani, A.N.; Baharlooi, H.; Djafarian, K. The Effect of L-carnitine Supplementation on Exercise-Induced Muscle Damage: A Systematic Review and Meta-Analysis of Randomized Clinical Trials. J. Am. Coll. Nutr. 2020. [CrossRef]

98. Chae, H.; Ryu, M.-H.; Ma, J.; Beck, M.; Kang, Y.K. Impact of L-carnitine on imatinib-related muscle cramps in patients with gastrointestinal stromal tumor. Investig. New Drugs. 2020, 38, 493-499. [CrossRef]

99. Malek Mahdavi, A.; Mahdavi, R.; Kolahi, S. Effects of L-carnitine Supplementation on Serum Inflammatory Factors and Matrix Metalloproteinase Enzymes in Females with Knee Osteoarthritis: A Randomized, Double-Blind, Placebo-Controlled Pilot Study. J. Am. Coll. Nutr. 2016, 35, 597-603. [CrossRef]

100. Kazemian, K.; Ala, S.; Mojtahedzadeh, M.; Abedini, M.; Alipour, A.; Abediankenari, S.; Rafati, M.; Abaskhanidavanloo, A.; Mohajerani, F. Evaluation of neuroprotective effects of L-carnitine and Fat emulsion in the CVA patients: A prospective, randomized, double blind, clinical trial. Iran. J. Pharm. Res. 2020, 19, 111-119. [CrossRef]

101. Di Stefano, G.; Di Lionardo, A.; Galosi, E.; Truini, A.; Cruccu, G. Acetyl- L-carnitine in painful peripheral neuropathy: A systematic review. J. Pain Res. 2019, 12, 1341-1351. [CrossRef] [PubMed]

102. Abolfathi, M.; Mohd-Yusof, B.N.; Hanipah, Z.N.; Redzwan, S.M.; Yusof, L.M.; Khosroshahi, M.Z. The effects of carnitine supplementation on clinical characteristics of patients with non-alcoholic fatty liver disease: A systematic review and meta-analysis of randomized controlled trials. Complement. Ther. Med. 2019, 102273. [CrossRef] [PubMed]

103. Thiagarajan, P.; Chalmers, J.; Ban, L.; Grindlay, D.; Aithal, G.P. L-carnitine supplementation in non-alcoholic fatty liver disease: A systematic review and meta-analysis. WJMA 2020, 8, 4-14. [CrossRef]

104. Askarpour, M.; Djafarian, K.; Ghaedi, E.; Sadeghi, O.; Sheikhi, A.; Shab-Bidar, S. Effect of L-carnitine Supplementation on Liver Enzymes: A Systematic Review and Meta-Analysis of Randomized Controlled Trials. Arch. Med. Res. 2020, 51, 82-94. [CrossRef] [PubMed]

105. Kido, J.; Inoue, H.; Shimotsu, H.; Yoshida, Y.; Suzuki, Y.; Nakamura, K.; Endo, F.; Matsumoto, S. Effect of L-carnitine on Amino Acid Metabolism in Elderly Patients Undergoing Regular Hemodialysis. Blood Purif. 2020. [CrossRef] [PubMed]

106. Safdar, O.; Jambi, G.; Asaad, O.; Hassan, L.; Al Dahlawi, L.; Halawani, A.F.; Jamjoom, M.; Shaikhoon, B.; Azhar, A.; Zaher, Z.F. L-carnitine effect on bone disease in hemodialysis pediatric patients in KAU Hospital, Jeddah Saudi Arabia: An experimental non-randomized study. Int. J. Med.Dev. Ctries. 2020, 4, 612-619. [CrossRef]

107. Koşan, C.; Sever, L.; Arısoy, N.; Çalışkan, S.; Kasapçopur, Ö. Carnitine supplementation improves apolipoprotein B levels in pediatric peritoneal dialysis patients. Pediatr. Nephrol. 2003, 18, 1184-1188. [CrossRef]

108. Sheikhi, A.; Djafarian, K.; Askarpour, M.; Shab-Bidar, S. The effects of supplementation with L-carnitine on apolipoproteins: A systematic review and meta-analysis of randomized trials. Eur. J. Pharmacol. 2019, 858, 172493. [CrossRef] 
109. Shimizu, S.; Takashima, H.; Tei, R.; Furukawa, T.; Okamura, M.; Kitai, M.; Nagura, C.; Maruyama, T.; Higuchi, T.; Abe, M. Prevalence of Carnitine Deficiency and Decreased Carnitine Levels in Patients on Peritoneal Dialysis. Nutrition 2019, 11, 2645. [CrossRef]

110. Bordoni, L.; Sawicka, A.K.; Szarmach, A.; Winklewski, P.J.; Olek, R.A.; Gabbianelli, R. A Pilot Study on the Effects of L-carnitine and Trimethylamine-N-Oxide on Platelet Mitochondrial DNA Methylation and CVD Biomarkers in Aged Women. Int. J. Mol. Sci. 2020, 21, 1047. [CrossRef]

111. Bavbek, N.; Akay, H.; Uz, B.; Uz, E.; Turgut, F.; Kanbay, M.; Senes, M.; Akcay, A.; Duranay, M. The effects of L-carnitine therapy on respiratory function tests in chronic hemodialysis patients. Ren. Fail. 2010, 32, 157-161. [CrossRef] [PubMed]

112. Sitta, A.; Vanzin, C.S.; Biancini, G.B.; Manfredini, V.; De Oliveira, A.; Wayhs, C.; Ribas, G.; Giugliani, L.; Schwartz, I.; Bohrer, D. Evidence that L-carnitine and selenium supplementation reduces oxidative stress in phenylketonuric patients. Cellul. Mol. Neurobiol. 2011, 31, 429-436. [CrossRef] [PubMed]

113. Jamilian, M.; Foroozanfard, F.; Kavossian, E.; Aghadavod, E.; Amirani, E.; Mahdavinia, M.; Mafi, A.; Asemi, Z. Carnitine and chromium co-supplementation affects mental health, hormonal, inflammatory, genetic, and oxidative stress parameters in women with polycystic ovary syndrome. J. Psychosom. Obst. Gyn. 2019. [CrossRef] [PubMed]

114. Hauschild, T.C.; Guerreiro, G.; Mescka, C.P.; Coelho, D.M.; Steffens, L.; Moura, D.J.; Manfredini, V.; Vargas, C.R. DNA damage induced by alloisoleucine and other metabolites in maple syrup urine disease and protective effect of L-carnitine. Toxicol. Vitro 2019, 57, 194-202. [CrossRef] [PubMed]

115. Cruciani, R.A.; Dvorkin, E.; Homel, P.; Malamud, S.; Culliney, B.; Lapin, J.; Portenoy, R.K.; Esteban-Cruciani, N. Safety, tolerability and symptom outcomes associated with L-carnitine supplementation in patients with cancer, fatigue, and carnitine deficiency: A phase I/II study. J. Pain Symptom Manag. 2006, 32, 551-559. [CrossRef]

116. Kraft, M.; Kraft, K.; Gärtner, S.; Mayerle, J.; Simon, P.; Weber, E.; Schütte, K.; Stieler, J.; Koula-Jenik, H.; Holzhauer, P. L-carnitine-supplementation in advanced pancreatic cancer (CARPAN)-a randomized multicentre trial. Nutr. J. 2012, 11, 52. [CrossRef]

117. Shirali, S.; Daneghian, S.; Hosseini, S.A.; Ashtary-Larky, D.; Daneghian, M.; Mirlohi, M.-S. Effect of caffeine co-ingested with carnitine on weight, body-fat percent, serum leptin and lipid profile changes in male teen soccer players: A randomized clinical trial. Int. J. Pediat. 2016, 4, 3685-3698.

118. Samimi, M.; Jamilian, M.; Ebrahimi, F.A.; Rahimi, M.; Tajbakhsh, B.; Asemi, Z. Oral carnitine supplementation reduces body weight and insulin resistance in women with polycystic ovary syndrome: A randomized, double-blind, placebo-controlled trial. Clin. Endocrinol. 2016, 84, 851-857. [CrossRef]

119. Ibrahim, N.A.M.; Mansour, Y.S.E.; Sulieman, A.A.; Hussein, H.S. A Local Study on the Effects of L-carnitine Supplement on Serum Lipid Profiles in Libyan Type 2 Diabetic Patients. IJARW 2020, 1, $28-32$.

120. Moradi, M.; Moradi, A.; Alemi, M.; Ahmadnia, H.; Abdi, H.; Ahmadi, A.; Bazargan-Hejazi, S. Safety and efficacy of clomiphene citrate and L-carnitine in idiopathic male infertility: A comparative study. Urol. J. 2010, 7, 188-193.

121. Malaguarnera, M.; Vacante, M.; Giordano, M.; Motta, M.; Bertino, G.; Pennisi, M.; Neri, S.; Malaguarnera, M.; Volti, G.L.; Galvano, F. L-carnitine supplementation improves hematological pattern in patients affected by HCV treated with Peg interferon- $\alpha$ 2b plus ribavirin. World J. Gastroenterol. WJG 2011, 17, 4414-4420. [CrossRef] [PubMed]

122. Mescka, C.P.; Guerreiro, G.; Hammerschmidt, T.; Faverzani, J.; de Moura Coelho, D.; Mandredini, V.; Wayhs, C.A.Y.; Wajner, M.; Dutra-Filho, C.S.; Vargas, C.R. L-carnitine supplementation decreases DNA damage in treated MSUD patients. Mutat. Res. 2015, 775, 43-47. [CrossRef] [PubMed]

123. Giammarioli, S.; Boniglia, C.; Carratu, B.; Ciarrocchi, M.; Chiarotti, F.; Mosca, M.; Sanzini, E. Use of food supplements and determinants of usage in a sample Italian adult population. Public Health Nutr. 2013, 16, 1768-1781. [CrossRef] [PubMed]

124. Santini, A.; Novellino, E. Nutraceuticals: Beyond the diet before the drugs. Curr. Bioact. Compounds 2014, 10, 1-12. [CrossRef]

125. Santini, A.; Novellino, E. To nutraceuticals and back: Rethinking a concept. Foods 2017, 6, 74. [CrossRef]

126. Abenavoli, L.; Izzo, A.A.; Milić, N.; Cicala, C.; Santini, A.; Capasso, R. Milk thistle (Silybum marianum): A concise overview on its chemistry, pharmacological, and nutraceutical uses in liver diseases. Phytother. Res. 2018, 32, 2202-2213. [CrossRef] 
127. Santini, A.; Tenore, G.C.; Novellino, E. Nutraceuticals: A paradigm of proactive medicine. Eur. J. Pharm. Sci. 2017, 96, 53-61. [CrossRef]

128. Daliu, P.; Santini, A.; Novellino, E. A decade of nutraceutical patents: Where are we now in 2018? Expert Opin. Ther. Pat. 2018, 28, 875-882. [CrossRef]

129. Durazzo, A.; Lucarini, M.; Santini, A. Nutraceuticals in Human Health. Foods 2020, 9, 370. [CrossRef]

130. Durazzo, A. Extractable and Non-extractable polyphenols: An overview. In Non-Extractable Polyphenols and Carotenoids: Importance in Human Nutrition and Health; Saura-Calixto, F., Pérez-Jiménez, J., Eds.; Royal Society of Chemistry: London, UK, 2018; pp. 1-37. [CrossRef]

131. Durazzo, A.; Lucarini, M. A current shot and re-thinking of antioxidant research strategy. Braz. J. Anal. Chem. 2018, 5, 9-11. [CrossRef]

132. Santini, A.; Novellino, E. Nutraceuticals-shedding light on the grey area between pharmaceuticals and food. Expert Rev. Clin. Pharmacol. 2018, 11, 545-547. [CrossRef] [PubMed]

133. Santini, A.; Cammarata, S.M.; Capone, G.; Ianaro, A.; Tenore, G.C.; Pani, L.; Novellino, E. Nutraceuticals: Opening the debate for a regulatory framework. Br. J. Clin. Pharmacol. 2018, 84, 659-672. [CrossRef]

134. Daliu, P.; Santini, A.; Novellino, E. From pharmaceuticals to nutraceuticals: Bridging disease prevention and management. Expert. Rev. Clin. Pharm. 2019, 12,1-7. [CrossRef] [PubMed]

135. Durazzo, A.; Lucarini, M. Extractable and non-extractable antioxidants. Molecules 2019, 24, 1933. [CrossRef] [PubMed]

136. Durazzo, A.; Lucarini, M.; Souto, E.B.; Cicala, C.; Caiazzo, E.; Izzo, A.A.; Novellino, E.; Santini, A. Polyphenols: A concise overview on the chemistry, occurrence, and human health. Phytother. Res. 2019, 33, 2221-2243. [CrossRef] [PubMed]

137. Virji, A. Potential benefits of L-carnitine as dietary supplement. Am. Fam. Phys. 2017, 96, 11.

138. de Andrés, F.; Castañeda, G.; Ríos, Á. Achiral liquid chromatography with circular dichroism detection for the determination of carnitine enantiomers in dietary supplements and pharmaceutical formulations. J. Pharm. Biomed. Anal. 2010, 51, 478-483. [CrossRef]

139. Sánchez-Hernández, L.; Castro-Puyana, M.; García-Ruiz, C.; Crego, A.L.; Marina, M.L. Determination of Land D-carnitine in dietary food supplements using capillary electrophoresis-tandem mass spectrometry. Food Chem. 2010, 120, 921-928. [CrossRef]

140. Isaguirre, A.C.; Acosta, G.; Cerutti, S.; Fernandez, L.P. New flow injection method for quality control of dietary supplements containing L-carnitine using extraction mediated by sodium taurodeoxycholate coacervate coupled to molecular fluorescence. Microchem. J. 2016, 129, 268-273. [CrossRef]

141. Voitiuk, O.; Yegorova, A.; Scrypynets, Y.V.; Kashutskyy, S.; Kluchnik, O.; Umetskaya, I. HPLC-determination of active components in dietary supplement « L-carnitine smart». Farmatsevtychnyi zhurnal 2019, 86-96. [CrossRef]

142. Ellingson, D.J.; Shippar, J.J.; Gilmore, J.M. Determination of free and total choline and carnitine in infant formula and adult/pediatric nutritional formula by liquid chromatography/tandem mass spectrometry (LC/MS/MS): Single-laboratory validation, first action 2015.10. J. AOAC Int. 2016, 99, 204-209. [CrossRef] [PubMed]

143. Johnson, D.W. An acid hydrolysis method for quantification of plasma free and total carnitine by flow injection tandem mass spectrometry. Clin. Biochem. 2010, 43, 1362-1367. [CrossRef] [PubMed]

144. Dwyer, J.T.; Saldanha, L.G.; Bailen, R.A.; Bailey, R.L.; Costello, R.B.; Betz, J.M.; Chang, F.F.; Goshorn, J.; Andrews, K.W.; Pehrsson, P.R. A free new dietary supplement label database for registered dietitian nutritionists. J. Acad. Nutr. Dietet. 2014, 114, 1517. [CrossRef] [PubMed]

145. DSLD-Dietary Supplement Label Database. Available online: https://dsld.nlm.nih.gov/dsld/ (accessed on 2 April 2020).

146. Brown, A.C. An overview of herb and dietary supplement efficacy, safety and government regulations in the United States with suggested improvements. Part 1 of 5 series. Food. Chem. Toxicol. 2017, 107, 449-471. [CrossRef]

147. Potischman, N.; Salazar, S.; Susser, J.; Saldanha, L.; Dwyer, J.; Kuzak, A.; Betz, J.; Bailen, R. Testing usability of the Dietary Supplement Label Database (DSLD): A resource for consumers, professionals, and researchers. J. Nutr. Edu. Behav. 2017, 49, S99. [CrossRef] 
148. Dwyer, J.T.; Bailen, R.A.; Saldanha, L.G.; Gahche, J.J.; Costello, R.B.; Betz, J.M.; Davis, C.D.; Bailey, R.L.; Potischman, N.; Ershow, A.G. The dietary supplement label database: Recent developments and applications. J. Nutr. 2018, 148, 1428S-1435S. [CrossRef]

149. Durazzo, A.; Camilli, E.; D’Addezio, L.; Piccinelli, R.; Mantur-Vierendeel, A.; Marletta, L.; Finglas, P.; Turrini, A.; Sette, S. Development of Dietary Supplement Label Database in Italy: Focus of FoodEx2 Coding. Nutrition 2020, 12, 89. [CrossRef]

150. Durazzo, A.; D’Addezio, L.; Camilli, E.; Piccinelli, R.; Turrini, A.; Marletta, L.; Marconi, S.; Lucarini, M.; Lisciani, S.; Gabrielli, P. From plant compounds to botanicals and back: A current snapshot. Molecules 2018, 23, 1844. [CrossRef]

151. European Food Safety Authority. Classification and description system FoodEx2 (revision 2). EFSA J. 2015, 12, EN-804.

152. Goin-Kochel, R.P.; Scaglia, F.; Schaaf, C.P.; Berry, L.N.; Dang, D.; Nowel, K.P.; Laakman, A.L.; Dowell, L.R.; Minard, C.G.; Loh, A. Side effects and behavioral outcomes following high-dose carnitine supplementation among young males with autism spectrum disorder: A pilot study. Glob. Pediatr. Health 2019, 6, 2333794X19830696. [CrossRef]

153. Malaguarnera, M.; Cauli, O. Effects of L-carnitine in Patients with Autism Spectrum Disorders: Review of Clinical Studies. Molecules 2019, 24, 4262. [CrossRef] [PubMed]

154. Asadi, M.; Rahimlou, M.; Shishehbor, F.; Mansoori, A. The effect of L-carnitine supplementation on lipid profile and glycaemic control in adults with cardiovascular risk factors: A systematic review and meta-analysis of randomized controlled clinical trials. Clin. Nutr. 2020, 39, 110-122. [CrossRef]

(C) 2020 by the authors. Licensee MDPI, Basel, Switzerland. This article is an open access article distributed under the terms and conditions of the Creative Commons Attribution (CC BY) license (http://creativecommons.org/licenses/by/4.0/). 